\title{
The Conditions of Subalternity: Reflections on Subjectivity, Experience and Hegemony
}

\author{
Peyman Vahabzadeh University of Victoria
}

\begin{abstract}
Résumé
Le présent article utilise la discussion des satis par Gayatri Spivak et le récit interprétatif de la mort de Chandra dans l'Inde coloniale par Ranajit Guha pour procéder à un nouvel examen critique du concept de subalternité présent dans diverses théories postcoloniales. Il avance que la théorie postcoloniale tend fréquemment à amalgamer hégémonie et domination. En introduisant le concept d'expérience, habilité par une lecture de la théorie d'Antonio Gramsci, l'article explore le rapport de la subalternité avec l'hégémonie et souligne que le succès ou l'échec de l'hégémonie dépend du degré auquel la nouvelle perspective de l'hégémonie parvient à maintenir le continuum existentiel du sujet.
\end{abstract}

\begin{abstract}
This paper uses Gayatri Spivak's discussion of Sati and Ranajit Guha's interpretive account of Chandra's death in colonial India in order to critically re-examine the concept of subalternity that runs through various postcolonial theories. It is argued that there is a major tendency in postcolonial theory to conflate hegemony with domination. By introducing the concept of experience, enabled by a reading of Antonio Gramsci's theory, the paper relates subalternity to hegemony and discusses that the success or failure of hegemony involves the degree to which hegemonic re-grounding can succeed in maintaining the existential continuum of the subject.
\end{abstract}




\section{Introduction}

This paper is motivated by a conceptual concern about the slippages that have permeated certain contemporary usages of Gramscian theory and concepts, due to the growing popularity of Gramsci in academia. Specifically, this paper makes an invitation to reconsider the concept of subalternity as it has become prevalent in postcolonial theory. By introducing the concept of experience as the totality of horizon of one's existence, this paper problematizes the under-theorized relationship between subalternity and hegemony in the works of two foremost postcolonial theorists. It has become somewhat of a truism in postcolonial theory to oppose subalternity to dominance. As such, subalternity is taken primarily as an ethical stance. This paper argues that although the ethical thread can certainly be identified in the Gramscian conception of the subaltern, ethical stance cannot be asserted at the expense of the existential-experiential aspect of subalternity. Showing the place of the concept of subalternity in the diverse body of works that we call postcolonial theory needs an extensive literature review which cannot be done in this paper. To narrow my focus, however, I will argue that a certain reading of the Gramscian theory of hegemony informs the postcolonial theories of Gayatri Spivak and Ranajit Guha, and that this reading does not yield a theory of subalternity that goes beyond an oppositional term vis-à-vis dominance. I will try to show that such an understanding of hegemony has transformed it into an extension of dominance, which is a simplification of Gramsci's concept. Likewise, the concept of subalternity, while a borrowing from Gramsci as well, has been transformed to fit the requirements of postcolonial or subaltern studies, but such transformation misses the existential aspect of Gramscian theory of hegemony-aspects that could indeed introduce new insights to social theory. It will be argued that the concept of experience will bridge the conceptual gap that exists in the relationship between hegemony and subalternity.

In order to concretize a very abstract question, this paper offers a reading of Ranajit Guha's account of Chandra's death in 1842 as well as Gayatri Spivak's renowned reflection on the practice of Sati under British colonial rule. To incise the under-theorized relationship between subalternity, hegemony, and experience, I will first briefly introduce the way Gramscian concepts are used in postcolonial theory. Next, I will discuss the two aforementioned cases (now classics in postcolonial studies). Then, I shall engage with the conceptual problems that inform the specific readings of these two cases as discussed by the two aforementioned prominent theorists. In this respect, one standard approach would be to offer a reading of Gramsci's theory first and then establish that Guha's and Spivak's application of concepts of hegemony and subalternity are unwarranted. The other approach is to actually show Guha's and Spivak's application of the aforementioned concepts and then try to introduce a certain reading of Gramsci's theory that would lead to a theoretically warranted understanding of hegemony and subalternity. I will pursue the second approach-ie. from the case to theory - because it will allow us to attune ourselves 
with the above-mentioned conceptual problem in an accurate way. But this approach requires patience from the reader, as it works more like diagnostic surgery.

\section{Chandra's Death and Enacted Legalisms}

The 1849 legal fragments in question, written in rustic Bangali, contain the depositions of three persons involved in the circumstances that led to the death of Chandra Chashani around 1842. Chandra died in her third month of pregnancy following an abortion and after her illicit love affair with Magaram Chashi was acknowledged to her family by him. According to the deposition of Bhagaboti Chashin, Chandra's mother, Magaram had told the family to arrange for abortion, "[o]r else, I shall put her into bhek." To evade bhek-that is, the "loss of caste by expulsion" or the "sentence of "living death"”-Chandra's family acquires and administers to her herbal medicine in order to destroy the foetus (Guha, 1987: 157). ${ }^{1}$ The foetus dies and is quickly buried at the outskirt of the village. Shortly afterwards, following an episode of fever, haemorrhage, and severe pain, Chandra also dies and is also buried outside the village. Chandra belonged to the Bagdis-a people who were "beyond the pale of the dominant caste in Hindu society ('dwellers on the outskirts of Hinduism') and another outside history itself" (Guha, 1987: 142). As agriculturist people, large numbers of the Bagdis worked in Western Bangal as landless day-labourers. According to Bagdi marriage rules, partners are to be selected from two different sections within the same sub-caste. Marriage rules therefore assure a network of alliances that in this case covered three villages forming a kinship group consisting of six Bagdi families.

Chandra's pregnancy threatened the kinship network of these families. The threat stemmed from the fact that "in nineteenth-century India sexuality was still subsumed in alliance for all social transactions....The control of sexuality therefore developed on those authorities and instruments... which governed the system of alliances" (Guha, 1987: 150). The birth of an illicit child would cause serious damage to the community thus constructed through sub-caste sectional alliances and governed by patriarchal morality.

Headed by a widow, Chandra's family included three children: two daughters called Chandra (the deceased), Brinda (the signatory of one of the depositions), and a third sibling who is omitted from the depositions. Chandra's transgression induces the fear of not only bhek (for Chandra) but also communal and kinship disturbance. The transgression activates the fear that is structurally existent in Bagdi society. Every reference to a woman in these documents begins with the singular first person possessive pronoun (my sister, my daughter). In Guha's words: "The paucity of male offenders in our sample is a telling index of patriarchal concern to exercise greater control over female than male sexuality" (Guha, 1987: 151). In all this, Chandra is absent and her absence is marked by a conspicuous silence. Her paramour Magaram Chashi is also absent in these documents; nevertheless, he is given a voice through one of the witnesses to utter his self-protection: "Abortion or bhek!" As such, the "lover of the night... becomes the law giver in the morning" (Das, 
1992: 323). Magaram transcends his particularity and becomes the universal patriarchal voice and the guardian of kinship. What is curious is that "the law does not see him [because] it doesn't have to" (Guha, 1987: 154). The investigation is carried out not by colonial court proceedings, but by the samaj (community) law-that is, by a village "tribunal" (Baxi, 1992: 251). As Upendra Baxi suggests, killing the foetus was not a violation of the colonial state's law, but of the samaj law: "the manner of Chandra's death, interrogates, even if for a moment, the legitimacy of the sanctions [against illegitimate foetus]" (Baxi, 1992: 256). Upon Chandra's death, the "samaj law loses its finite legal powers not just over Chandra but those who arranged for her abortion. The samaj law could not possibly accuse them of violation of its norms" (Baxi, 1992: 256). By not seeing Magaram, the law takes his patriarchal motive for granted. Thereby the legal discourse identifies with the patriarchal laws governing kinship in Bagdi society. In the silence of her deceased sister, however, Chandra's sister Brinda voices her own subjectivity into the legally imposed subjectivity as a defendant: "I administered the medicine in the belief that it would terminate her pregnancy and did not realise that it would kill her" (Guha, 1987: 161). As Guha observes, her "utterance... defies the ruse of law and confers on this text the dignity of a tragic discourse" (1987: 161).

Thus, Chandra's death mobilizes a relation of solidarity among the women of these villages. "The solidarity born out of fear contained within it another solidarity activated by a different, indeed contradictory, principle-namely empathy," avers Guha (1987: 160). "If it was the power of patriarchy which brought about the first, it was the understanding of woman which inspired the second" (Guha, 1987: 160). Magaram, in fact, represents this kind of solidarity. However, fear also invokes another kind of solidarity; a sympathetic solidarity (Guha, 1987). "Under these circumstances their decision to go ahead with the termination of pregnancy acquired a content very different from what Magaram had on his mind when he confronted her mother with that alternative. It was for him merely a ploy to save his own face" (Guha, 1987: 161). Such was certainly not the case with the women involved in Chandra's abortion, according to Guha's reading. Their involvement in fact marks their "consciously adopted strategy to prevent the social destruction of another woman, to fight for her right to a life with honour within her own society" (Guha, 1987: 162). These women know that childbirth is a social event that ultimately excludes the male decision. The knowledge that a woman's body is ultimately hers (as she is the sole nurturer of the foetus) enables these women to dwell at this moment of crisis "in an area of liminality not strictly governed by the will of husbands and fathers" (Guha, 1987: 163). Chandra, therefore, has recourse to an alternative solidarity-namely, solidarity of women. The irony of Chandra's death lies in that she lost her life "by the very act which was meant to save her from living death in a ghetto of social rejects. Yet here, as in all tragedies, the triumph of fate helped to enhance rather than diminish human dignity-the dignity of the woman's choice to terminate the pregnancy and their determination to act according 
to it" (Guha, 1987: 161). Chandra's death is therefore an unintended consequence of her empathic solidarity.

While the dread of kinship implosion, which would be invoked by Chandra's transgression, exists within the structure of the life-world within which Chandra's voluntarism becomes meaningful, it is the assent of the subject, hegemonized by the powerful grip of an imminently coercive tradition, that makes the practice intelligible, in fact possible. The tragedy of Chandra's death is lost in the legal discourse, despite the appreciable attempts of a sympathetic postcolonial reader/scholar (Ranajit Guha) to retrieve such tragedy from between the lines of soulless legal documents. To the legal discourse, the widow's word was not sufficient and it had to be supported by the deposition of the medicine man - a man of the same seniority as her lost husband who was allied to Chandra's mother through marriage. The legal documentation of this event decontextualizes Chandra's death by breaking the narrative of defendants into legally imposed codified fragments. It contains the speech of the three defendants, but the speech itself is prompted by the authority of legal investigation (Guha, 1987). The legal discourse, therefore, functions to transform "a matrix of real historical experiences" into "a matrix of abstract legality," thereby "detaching an experience from its living context" (Guha, 1987: 140). The actual sequence of events and the deepseated social circumstances is violated to keep the narrative in conformity with the logic of legal intervention-a logic that turns death into murder. A logic, one is inclined to add, that despite its humanist gestures (as colonialism was propagated as an expansion of European humanism over the 'backward' world), leaves the most archaic practices of a tradition in its place, since such practices do not undermine the colonial humanist pretense.

Chandra's death introduces us to the condition of displacement of the subject. Entangled in the strict social relations of a hegemonic patriarchy, Chandra's decision to undergo an abortion and her subsequent death is displaced within the patriarchal domination of the samaj law in the disinterested presence of the colonial legal discourse. ${ }^{2}$ Whereas Chandra had only a small voice under the samaj law, she was totally deprived of a voice under the colonial legal edifice. "The subaltern discourse," as Upendra Baxi observes, "imposed by both the samaj law and the hegemonic judicature, silences Chandra just when she should speak to us" (1992: 256). Moreover, Guha's reference to solidarity indicates his desire to channel into the subaltern consciousness, but that is ultimately impossible under the conditions of the double silencing of Chandra. Only when Chandra can speak, and by so doing put an end to her subalternity (see Spivak below) can we approximate her subaltern consciousness. For, aside from these deposition fragments, we only have tradition, the samaj law, and the colonial discourse to locate her consciousness within the general structure of intelligibility of her society and time. We will unavoidably arrive at the realm of indeterminacy when we ask ourselves whether Chandra's decision to go ahead with the abortion represented a mode of speaking and resistance or one of panoptic 
self-subjugation. This indeterminacy reveals itself in Guha's and Baxi's disagreement on whether Chandra's decision should be read as an act of resistance against the hegemony of the law. Guha holds that "when a victim, however timid, comes to regard herself as an object of injustice, she already steps into the role of a critic of the system that victimises her [note the feminine pronoun]. And any action that follows from that critique contains the element of a practice of resistance" (Guha, 1987: 165). Baxi, on the contrary, reads Chandra's death in a different light:

Ranajit Guha brings us live, as it were, the victim's resistance to victimage. In excluding males from their activities of arranging an abortion for Chandra, the Bagdi women do not acquiesce in, much less internalize, the legitimacy of the samaj laws. But in acquiesce in the either/or alternative of samaj law and justice-abortion or bhek, the women take over the enforcement of samaj law on themselves. In choosing abortion, they preclude bhek. But the manner of Chandra's death, interrogates, even if for a moment, the legitimacy of the sanctions (1992: 255-56).

All legalities, traditional or colonial, enacted to categorize the case and its actors into codified rules of social conduct, ultimately fail to contain the metonymy of the case. However, this kind of categorization of acts, and correspondingly of actors as subjects of different hegemonic-legal regimes, leads to indeterminacy only after the intervention of the scholar.

Now let us make some preliminary observations: in my view, the above indeterminacy between solidarity out-of-fear and solidarity out-of-sympathy is symptomatic of a serious lack of attention to the totality of hegemonic experience of the subject (colonial or not) - a totality that can be penetrated by various or opposing hegemonic discourses, but cannot be ruptured as a result. I would like to argue that under the conditions of subalternity, any genuine experience becomes transgressive while at the same time that very experience reveals nothing but the condition of subalternity. That is to say, any act of transgression, as it sees a possibility beyond the hegemonic grounding of everyday experience, immediately drives the subject to subalternity. This is evident in Chandra's decision: to undergo abortion entails a violent patriarchal move against the transgressive act of Chandra (illicit love affair). On the one hand, by virtue of her transgressive act, the hegemonized subject becomes the dominated subaltern. On the other hand, her fateful acceptance of abortion reveals the subject's decision to stay within (or return to) the perimeters of patriarchal hegemony, thus true to her hegemonized experience of the delicate Bagdi society, and thereby resisting the conditions of her subalternity. Here we must recall that Gramsci (1971) recognized that subalternity refers to the situation in which one class becomes subjected to the decisions of another. Subalternity cannot be explained in hegemonic terms, because it is achieved through subordination and silencing. 
The attentive reader is aware that I am persuading her or him into making a distinction between hegemonized subject and dominated subaltern - a distinction that in my reading comes from Gramsci, but is often ignored in Gramscian literature. Subalternity closes the subaltern's experience down unto itself. The hegemonized subject, on the contrary, does relate to the hegemonic horizon of her or his existence through experience. "Abortion or bhek!"3 signifies the opposition of hegemonic conformism and subaltern exclusion, but not as if they are mutually exclusive. Rather, the very knowledge of bhek as the threat of subaltern exclusion is achieved through the hegemonic experience of norms of Bagdi society. In itself, bhek remains an obscure threat and a dimming of the total horizon of hegemonic experience consequential to the transgressive act of a Bagdi woman. Bhek, as a daunting prospect, is the moment of the failure of consent and recourse to coercion, to use Gramscian terms. Guha's analysis does not effectively conceptualize the notion of experience in the manner that informs Gramsci's theory of hegemony, to which we shall attend later. As a result of this conceptual defect, Guha tries to bridge the gap between Chandra's subjectivity and the discourse that (de-/re-)contextualizes her death through the sympathetic reading (however commendable) of the scholar-advocate.

\section{Sati and the Double Constitution of the Hindu Woman}

Equally compelling a case about subalternity is that of Sati (suttee in colonial discourse, the Sanskrit for 'widow'): here we have a sharp contrast between the native tradition and the colonial intervention. Sati, as is well known, refers to the practice of the Hindu widow self-sacrifice upon dead husband's cremation. The practice, as Gayatri Spivak observes, was not universal. Although according to the Hindu scriptures suicide is condemnable, the widow self-sacrifice supposedly signifies an outstanding demonstration of a presumably exorbitant widow's love of her lost husband. The subtext of Sati, as one might surmise, is the women's power over property. It would not therefore be too dubious a conclusion to claim that Sati provided for the surviving male members of the family a unique opportunity to rid of the widow (Spivak, 1988a).

Under British colonial rule, the practice was banned. Thus emerged the head-on encounter of the colonial philanthropic discourse of liberal individualism with the Hindu nativism and its claim toward the voluntarism of widow participation in this ritual. The counterpositional discourses of "[w]hite man saving brown women from brown men" versus "the woman actually wanted to die" offers a binary with no prospect of resolution (Spivak, 1988a: 297). While nativism saw Sati as "reward," imperialism defined it as "punishment" (Spivak, 1988a: 301). In the colonial context, then, Sati comes to be automatically included in the chain of equivalential signifiers of anti-colonial resistance ${ }^{4}$ : it receives meaning from the potential of acting toward anti-colonial insurgency. Now, as Spivak (1988a: 299) states: "Imperialism's image as the establisher of the good society is marked by the espousal of the woman as object of protection from her own kind. How should one examine the

3 Guha (1987: 157).

4 See also Laclau and Mouffe (1985: 131). 
dissimulation of patriarchal strategy, which apparently grants the woman free choice as subject? In other words, how does one make the move from 'Britain' to 'Hinduism'?" The mutually exclusive counter-positioning of the Hindu woman in the antagonistic discourses indicates the radical unfixity of the Hindu woman as a political signifier. On the one hand, there is the imperialist white man's constitution of the 'brown woman' as an object of deliverance. On the other, there is the patriarchal Hindu construction of the female subject (Spivak, 1988a).

Interestingly, the Hindu woman herself does not have a voice in such a sharp counterposition between two irreducible poles, which, subsequently, are mutually legitimising (Spivak, 1988a). Here the notion of 'voice' is key. For, both camps are intent upon giving a voice to the subaltern woman, thereby representing her free will vis-à-vis the Other (Moore-Gilbert, 1997). Spivak (1988a: 300), therefore, locates in Sati what Lyotard called differend-that is, "the inacessibility of, or untranslatability from, one mode of discourse in a dispute to another". Between the two antagonistic counter-positionings, the Hindu woman "disappears, not into a pristine nothingness, but into a violent shuttling which is the displaced figuration of the 'third-world woman' caught between tradition and modernization." Thus Sati signifies the case that "the woman-in-imperialism would challenge and deconstruct [the] opposition between subject (law) and object-of-knowledge (repression) and mark the place of "disappearance" with something other than silence and nonexistence, a violent aporia between subject and object status" (Spivak, 1988a: 306). Consequently, the vying invasion of the loci of the constitution of Hindu woman - by the imperialist humanism (an oxymoron indeed), on the one hand, and by Hindu patriarchy, on the other-deprives the woman of subjectivity and of the space from which she can speak (Spivak, 1988a).

Spivak's account of Sati, derived from the speech act theory, leaves an important point almost completely unuttered: that the two competing discourses in fact represent two rival hegemonic principles intent upon hegemonizing the 'Hindu woman.' Note the biased dualism on Spivak's part: the widow is an object of British humanism, but a subject of Hindu patriarchy. It is biased because Spivak recognizes, for good reasons, the Hindu woman's subjectivity within her patriarchal structure. But this suggests that the woman cannot also be the subject of British protection (hence Spivak's usage of the term 'object'). What in Spivak's observation is missing is the absence of notion of two competing hegemonic principles, each trying to slip under the widow's subjectivity in an attempt at providing a potential total-horizon of experience (note, however, that so long as these principles challenge one another so fiercely, they fail). Not seeing the counterpositioned discourses as hegemonic principles at work, Spivak still deems the position of the woman as subaltern-a conceptualization that accords with Gramsci's understanding of the concept. The conceptual problem, however, shows itself when Spivak speaks of the 
loss of the voice of the Hindu woman, as though the subjectivity of the Hindu woman can supersede the hegemonic total-horizon in which she is inserted. The argument I wish to make here can be illustrated through a hypothetical case: let us suppose that the Hindu widow refuses Sati. In this case, her refusal would constitute an act of transgression sufficiently threatening to the hegemonic experience of the Hindu tradition, in which case she would be entitled to some sort of social retribution. But since outside the hegemony of tradition there awaits the potential hegemony-or counter-hegemony-of British imperial humanism, the existing chain of equivalences will automatically place the widow's act under the auspices of colonial hegemony. Whether the Hindu woman is aware of the consequences of her transgressive subjectivity, her act of refusal would link her to a hegemonic principle that, apparently, encourages humanism and individual choice. In other words, if our hypothetical widow refuses sati, she transgresses the existing hegemonic norms, which would throw her outside the tradition and into the British humanist hegemony. We shall return to this discussion shortly, but here, one can see how Spivak indeed sympathizes with the widow (as did Guha with Chandra) and in the end endorses a humanist position. Note also, that I have cautiously used the term 'counterhegemony' to refer to the situation in which two different hegemonic discourses, based on very different principles, compete on hegemonizing the Hindu woman (or any actor for that matter). The term 'counter-hegemony', however, is often used to denote the subject's acts of resistance against the existing hegemony. I find this usage of the term inaccurate and contrary to Gramsci's understanding of hegemony; insofar as the subject is constituted by a certain hegemonic principle and lives within the ambits of hegemonic total-horizon, even acts of resistance against hegemony are hegemonic because the mode and exercise of such acts are conditioned by the existing hegemonic principles.

\section{Epistemic Knowledge and Marginalization}

To focus our investigation on the conditions of subalternity, it is first necessary to discuss the relationship between marginalization and epistemic knowledge. Marginalization is always a by-product of claims to 'authentic' hegemonic knowledges. Spivak's reflection on the operation of marginalization shows that claims to authentic knowledge exist in any centre-margin relation. She argues that the centre always tries to present itself as having super-knowledge about the Other such that the logic of appearance of this ontological privilege deters those out of the centre from scrutinizing its "transcendental idealisms" (Spivak, 1987a: 103). The centre remains the centre so long as it can provide explanations. To return to our discussion above, the fierce rivalry between British humanism and Hindu nativism on the issue of Sati intended to capture the central explanatory position based on competing hegemonic principles. By objectifying its rival's knowledges, Edward Said (1979) observes, each side of the colonial binary neutralises the other's threat.

An explanation always posits an explainable and an explaining subject. As such, any 
explanation tends to "secure and assure a certain kind of being-in-the-world, which might as well be called our politics" (Spivak, 1987a: 106). Not just another form of being, this being-in-the-world tends to expand itself via the universalization of its particular epistemology. "Explaining," Spivak remarks, "we exclude the possibility of the radically heterogeneous" (1987a: 105). Homi Bhabha and Spivak refer to this kind of exclusion as "epistemic violence" (Bhabha, 1994: 42; Spivak, 1990: 77) and define it as the imposition of one single frame of reference upon others. This frame of reference results from the tendency endemic to all explanations: that the explanations' claim to centrality is made at the expense of the exclusion of margins (Spivak, 1987a). The explanation, therefore, is always the sign of authority (Bhabha, 1994). Idioms of resistance such as Sati under the effect of equivalential relations challenge such authority in an attempt at justifying the explanatory frame of resistance.

Marginality, then, emerges through questioning the structure of an explanation. Probing the structure of an explanation, the questioning subject poses a potential threat to the ideological means of production of the explanation. Thus, marginality is "a suspicion that what is at the center often hides a repression" (Bhabha, 1994: 104). In a deconstructive manner, Spivak (1987a) concludes that the marginal's articulatory practice shows the inexhaustibility of the margin by the explanation. This does not necessarily mean that the margin is trying to reverse the process of marginalization. The margin, however, could certainly create dislocations in the relationship between centre and margin, because by criticizing the centre, the marginal implicates itself in the centre. Such a dislocation, however, prompts the centre to enfold, however uneasily, some selected dwellers of the margin (like the local elite classes in the colonized society) only in order to better exclude the marginal, for by so doing, the centre wins more legitimacy for its frame of explanation. But there are always those remaining marginalized elements that cannot be incorporated into the existing epistemic framework. Hence, the centre needs a "fence of consistency" to "fence out" those marginals whose inconsistency with the centre causes them to be incompatible with it (Spivak, 1987a: 114).

Accordingly, Spivak subverts the objective view that seeks to identify the sources of centre-margin relationship with forces outside the relationship itself. Seeking an objective source of explanation posits a universal epistemology. But if subalternity begins with absolute marginalization under an epistemic frame of explanation, then one is inclined to ask: "Where does cognition begin and end?" While reporting a decision based on a marginalized or fenced-out explanation, a transgressive act is potentially the endpoint in subalternity, the rebellious instant and a moment of refusal against the hegemonic principle under whose sway everything is to be experienced in certain ways and according to certain epistemic explanatory frameworks. Referring to the colonial India, Ranajit Guha specifies that the subalternity of the Indian peasant was materialized by the structure 
of property, institutionalized by law, sanctioned by religion and made tolerable - and even desirable-by tradition. To rebel was indeed to destroy many of those familiar signs, which he had learned to read and manipulate in order to extract meaning out of the harsh world around him. The risk of 'turning things upside down', the horizon of an utterly radical transformation was indeed so daunting that he could hardly afford to engage in such a project (Ghua, 1988). Transgression, one might add, is never just another option, once one considers (as in "abortion or bhek!"5) the consequences of such radically lifealtering act.

By definition, the "subaltern cannot speak" because, as Spivak (1988a: 308) put it, "[r]epresentation has not withered away." She gives her analysis a Gramscian turn by stating that when the subaltern speaks he or she becomes the organic intellectual (Landry and MacLean, 1996). Stated differently, insofar as the structure of explanation is so transparently blended with that of domination, the subaltern cannot speak in her own terms. From the vantage point of speech act theory, speaking refers to "a transaction between the speaker and the listener. That is what did not happen in the case of a woman who took her own body at the moment of death to inscribe a certain kind of undermining - too weak a word - a certain kind of annulment of all the presuppositions that underlie the regulative phychobiography that writes Sati" (Landry and MacLean, 1996: 289). The widow, in other words, cannot speak back to the speech addressed to her by the structure of Hindu patriarchy (which in this particular case is uttered in the language of Sati). Nor could Chandra ever respond to the structure of Bagdi society in terms other than "abortion or bhek!"6 Chandra could have never spoken. But neither could have the Sati widow, for she was never even spoken to by the colonial humanist discourse that, ironically, intended to save her. These living subjects of colonialism were never heard. Neither the structure of precolonial, patriarchal domination, nor that of a colonial power, would speak to the subaltern in an attempt at creating an interlocution. The 'small voices' of the subaltern were therefore lost in the competing demands and commands of competing hegemonies. The condition of possibility of listening, indeed hearing, is a structural openness (Guha, 1996). Neither the precolonial structure trying to maintain traditional authority nor the colonial power so rigorously seeking a formal-institutional footing in Indian society desired to succumb to such openness in the presence of a competing discourse. Therefore, the moment of insurgency-especially, but by no means exclusively, in the colonial context-is the true moment of subaltern's speaking in his or her own terms. It is the moment of self-representation.

What is missing in Spivak's well-argued discussion is the concept of hegemony. What is continually assumed, but at the same time consistently asserted, is the existence of a subaltern consciousness that seems to be somehow imprisoned by the structures of domination. All knowledges have their roots in particular existential contexts 
and experiences. Knowledge becomes epistemic when it is hegemonized, when the "spontaneous philosophy" of a social group is systematized and universalized through institutionalization and is therefore brought under the interests and worldviews of another social group (Gramsci, 1971: 323). Gramsci once wrote: "In acquiring one's conception of the world one always belongs to a particular grouping which is that of all the social elements which share the same mode of thinking and acting" (1971: 324). Epistemic knowledge is gained when a shared but particular explanatory frame becomes universal (and is thus de-contextualized). Marginality could be the by-product of hegemonic universalization of a particular body of knowledge and experience, but it is important to note that by creating expansive life-horizons that are nonetheless anchored to the existing hegemonic principle(s), all hegemonies have a tendency to reduce marginalization. As such, contrary to Spivak's assertion, marginality does not disturb the centre-margin binary. If we agree that the task of colonialism was indeed to pass beyond dominance and achieve hegemonic consent ${ }^{7}$, then the only way a leading epistemic knowledge could have been achieved was through offering explanations that would immediately establish meaningful links with the common sense and experiences of the colonized masses. The defining experiences of the colonial subject must be channeled to the colonial frame of explanation. Agonizing as it sounds, a hegemony such as this could not be achieved without extracting knowledge from the very subjects whom colonial power once subjugated and now intends to protect (sati). Let us elaborate on this point in our concluding remarks about the relationship between subalternity, hegemony and experience. But let us also note here that while the two prominent postcolonial theorists utilize the Gramscian concept of 'subaltern' as their guiding concept, in effect they take the term hegemony (without which subalternity cannot be properly understood) as more or less equivalent to dominance - an unfortunate slippage and a sign of unsophisticated reading of Gramsci, that with the popularization of his theory in academe has nowadays become widespread. ${ }^{8}$

\section{Hegemony and Dominance in the Colonial Context}

As is well known, postcolonial theorists (especially the scholars of the Subaltern Studies Group) have utilized, with more than a pinch of Derridean deconstruction, the Gramscian concepts of hegemony and subalternity in order to apply it to the question of colonial domination. The distinguishing feature of colonialism lies in that, at least in its initial stages, it is realized primarily through direct exercise of force, whether by the imperial army and administration, the comprador elite, or local warlords. Hegemony always remains the utter goal (or hope) that may be realized after the establishment of the colonial rule. Theoretically, this curious situation has been captured and well explained by Machiavelli's splendid work on principalities in the context of Italian city-states, whose relations with one another resemble the colonial context (Machiavelli, 1979). Much of what Gramsci has formulated in terms of hegemony are indeed informed by his deep understanding of Machiavelli.

7 Gramsci (1971).

8 See Day (2005). 
In studying the colonial context, as in the aforementioned cases, there is a tendency to conceptualise hegemony more as dominance and coercion than consent. Along the Gramscian line, Guha (1992: 72) defines hegemony as "a condition of dominance in which the moment of persuasion outweighs that of coercion". But the fact that he always discusses hegemony with reference to dominance ${ }^{9}$ implies that he does not lose sight of the violent moment of the complex colonial institution of the colonized. Here a terminological distinction seems to operate in Guha's theory: 'dominance' can contain both coercion and consent (his term: 'persuasion'). As such, he uses 'dominance' the way Gramsci uses such terms as 'the state' or 'dominant social group.' Generally speaking, dominance holds an important and growing hegemonic core within it. But what is mute in Guha's theory is a discussion on how precisely a dominant force is poised to find the right measure of coercion and consent, for such delicate measure is indeed the prerequisite in establishing hegemony. To address this lack in postcolonial theory we need to reread Gramsci and establish the concept of 'experience'-to which Gramsci so frequently referred when speaking of 'common sense' and élan vital-as the realm in which the process of hegemonization takes place.

I would therefore like to begin by suggesting that hegemony involves a re-grounding of everyday experience and common sense in the epistemic framework of the hegemonic class or group. The affinity between hegemony and dominance also means that, due to the conquest of an Other, the constellation of dominance in colonial rule is never pre-given (Guha, 1989). By definition, dominance brings with it subordination. The incommensurability of Sati with British philanthropic humanism exemplifies the failure of colonialism in becoming hegemonic in many realms of life of colonial India. Humanism could not, in other words, re-ground, at least at the peak of colonialism's social (not military) confrontation with the locals, the life-world of Hindu society. Consequently, the widow, already deprived of a voice under Hindu patriarchy, was never given a voice by British humanism either. The latter certainly offered no language (at the time anyway) capable of enabling the Hindu widow to articulate her experience. Since imperialism failed to hegemonize the Hindu woman, it turned her into the object of (colonial) state protection. Ironically, then, imperialism could only protect a subaltern and silenced woman. On the other hand, the hegemony of Hindu nativism, perpetuated through tradition, did not succeed in hegemonizing Hindu woman as woman either (due to patriarchal structure); it turned the Hindu woman into the Hindu female subject. The female subject was thus the paradoxical (not to mention reluctant) subject of an age-long tradition. Let us recall that the ambivalence surrounding Chandra's decision is only meaningful in the ambience of such subordination. Although different in terms of discourses, Chandra and the Hindu widow in Sati are prime depictions of subalternity as the denial of the subjectivity of the subject. ${ }^{10}$ The colonial rift between the rulers and the ruled, which the intended colonial hegemony of British humanism intends to overcome, stems precisely from this binary constitution

9 See Guha (1989).

10 See Das (1992). 
of dominance and subordination. While according to Guha (1989), domination refers to the colonizer's political culture, subordination refers to the precolonial political-cultural tradition. Therefore, the schism is perpetuated, for in dominance without hegemony civil society (supposing that there is one; in colonial context there is only a small civil society mainly consisting of the local elite) cannot be fully absorbed into activity of the state. The picture becomes more complicated once we also heed the nationalist elite's shaky humanist role, which was itself constituted by the Western discourse of the liberal, autonomous subject as the master of his or her own destiny in building a hegemonic bloc with the masses. The local elite must face the dominance that emanates from the colonial power, which by virtue of its being a Western colonial rule is doubly constituted by domination and humanism. And paradoxically, the colonial rule has to 'rectify' the problem of the tradition that sanctions dominance and autocracy. ${ }^{11}$

In the colonial context, the term subaltern becomes a strictly oppositional identity. When it comes to the subaltern identity, Guha's earlier definition falls prey to the objective terms it uses: he defines the subaltern classes as the social groups and elements that "represent the demographic difference between the total Indian population and all those whom we have described as the 'elite'" (1982: 8). The fallacy of this definition lies in that it is entirely a construct of the historian, and as such, it tends to homogenize the subaltern as the object of the historian's pursuit. Consider also, Gramsci's definition of subaltern groups as those "always subject to the activity of ruling groups, even when they rebel and rise up" (1971: 55). For postcolonial theorists, the point is not to achieve objectivity by maintaining a distance with the subject, but to arrive at a description through approximation. After all, how can one make sense of Chandra's death otherwise than through approximation? Does Guha's elegy not above all pursue an empathetic proximity? While some scholars have defined subaltern in oppositional terms ${ }^{12}$, others have tried to overcome the binary (so naturally embedded in morphological categories) by depicting the ultimate indeterminacy that permeates the subaltern consciousness. Partha Chatterjee eliminates the binary by pointing out that "subaltern consciousness is not merely structure, characterised solely by negativity; it is also history, shaped and developed through a changing process of interaction between the dominant and the subordinate" (1992: 206). The introduction of colonial dominance, therefore, will inadvertently introduce to the consciousness of the subaltern the terms and conditions of its own overcoming. Many Indian insurgents, for instance, derived their terms of protest from the very structure denied to them and against which they rose up - that is, to state it simply, from the liberal humanist notion of the citizen's rights (indeed: a 'people's rights') to autonomy and self-determination and, in a strangely oblique way, to the British democratic tradition. One is inclined to add that so was the case with the nativist argument in favour of Sati that emphasized the 'free will' and individual choice of the woman who 'wanted to die!' This, among other things, means that while the history of subaltern is "fragmented and episodic" (Gramsci, 1971: 54-55), the subaltern

11 See Guha (1992).

12 See Sen (1987) and Chakrabarty (1985). 
consciousness is not necessarily episodic and sporadic unless the subaltern is ruptured by different subject positions. ${ }^{13}$ In other words, episodic consciousness is not an effect of subalternity but of the subject's split across different groups, or in the colonial case (Sati), across competing hegemonic principles and their aspired universalization(s). However, the life-world within which the subject is inserted is by definition a totality that is achieved through an existential continuum-that is, through experience and commonsense, which I have discussed elsewhere (Vahabzadeh, 2003). Let me elaborate.

\section{Subjectivity, Hegemony, Experience: Back to Gramsci}

To understand Gramsci's theory of hegemony, insofar as it pertains our predicament here, one must begin by acknowledging the double sense of hegemony in Gramsci. Hegemony refers to a state of affairs that involves governance, but it also signifies the moment of political reinstitution of society. Both senses of the term are heavily influenced by Machiavelli ${ }^{14}$, although the genealogy of the concept can be (remotely) traced back, despite Gramsci's own acknowledgment, to Lenin and the Second International ${ }^{15}$, various schools of Italian Hegelian philosophy ${ }^{16}$, as well as to linguistics ${ }^{17}$. Now the question is: if society in fact represents a continuum, and if politics, as an attempt at reinventing and reinstituting society according to certain principles, is about making inroads into the life of society based on common sense and shared worldviews, then how is the tension between continuity and change negotiated? We know that Gramsci clearly rejected the determinism of the economic base that involved the purging of the old in favour of the new (which he called "catharsis"18) - a rather simplistic answer to the above predicament provided by many Marxists. "The philosophy of praxis," 19 he wrote, "was being elaborated in the same direction and the moment of 'hegemony' or cultural direction was precisely being reevaluated in opposition to the mechanistic and fatalistic conceptions of economism" (Gramsci, 1994: 169). Acknowledging that there is no simple answer to the question of continuity and change, especially insofar as it involves hegemony (that contains the combined effects of coercion and consent), Gramsci seeks the answer in the cultural realm. This allows him to pay due attention to civil society where the relevant social and political "trenches" ${ }^{20}$ and issues can be captured by the subaltern alliance of proletarians and peasants. Gramsci cleverly observes that issues become relevant to specific social

13 Note Gramsci's description of the concept of subject positions: "When one's conception of the world is not critical and coherent but disjointed and episodic, one belongs simultaneously to a multiplicity of mass human groups" (1971: 324).

14 Gramsci (1971).

15 Gramsci (1971).

16 Golding (1992).

17 Ives (2004).

18 Gramsci (1971: 366-67).

19 Gramsci (1971: 381).

20 Gramsci (1971: 243). 
groups because they have direct bearing on their everyday, material lives. But such issues, and the demands they invoke, will remain fragmented if they are not unified by a political program. Now the aim of the hegemonic program of subaltern groups is to make meaningful connections between, on the one hand, fragmented demands of various subaltern groups, and on the other hand, the universal and cohesive worldview of the subaltern leadership (in his case, the modern Prince, the Communist Party). In other words, the united bloc of subaltern classes would not be possible without making a connection between experiences of fragmented subaltern groups - the experiences that translate into issues and demands due to the articulation of the modern Prince-and a political program. Gramsci's emphasis on the cultural realm rests on the observation that only through a cultural campaign can one successfully articulate between experiential knowledges of the subaltern and the programs of a political front. As such, the experiential knowledges of the masses (continuity) link them to their new hegemonic leaders (change). I call this the 'hegemonic re-grounding' of experience. Note, as mentioned, the term 'counter-hegemony' is unwarranted, should one decide to stay in line with Gramsci's understanding, because since the subaltern are subject to hegemonic decisions, their political programs are (at least in part if not entirely) shaped up by the existing hegemonic principles and the worldview they emanate upon social life. One can only speak of counter-hegemony in the contexts of competing discourses such as those of colonial vis-à-vis nativist, or in Machiavelli, between competing principalitiesthat is, when two hegemonic principles stand in direct opposition with one another without sharing the epistemic fields (recall the example of Sati).

The hegemonic re-grounding does not necessarily bring together the so-called fragmented consciousness of the divided subaltern (divided across subject positions); rather, it displaces the life-world in its entirety (with its internal divisions as well as coherences) unto a new ground, indeed unto a new total-horizon. It is by virtue of hegemonic re-grounding of the exiting experiences, through which everyday experiences and their concomitant tacit knowledges are realigned with the triumphant hegemonic principle(s), which the subaltern could potentially transform into the hegemonic subject. It is this subject that would give its consent to the arising (or existing) hegemony. There remains, though, in every subject something of a subaltern and in every subaltern a bit of a hegemonic subject. The exact configuration of the contiguity of subject and subaltern within each class or social group is dependent upon the hegemonic principles as well as the subject position each subject/ subaltern occupies within the existing hegemonic social relations. It is precisely such an understanding of the concept of hegemony and the mutual incompleteness of both subject and subaltern that postcolonial theory, as represented by the two archetypical cases above, lacks.

Reflecting on our cases, while Chandra's decision kept her within the existing hegemonic total-horizon (and she paid dearly for her decision), the Sati controversy shows the ultimate 
impossibility of hegemonic re-grounding and transference of the subject from the nativist total-horizon to a liberal-humanist (and colonial) one, insofar as the defining terms of competing hegemonies remain so vehemently oppositional.

Now let us revisit another key point: the condition of subalternity, as Spivak argues, is not-speaking. The condition of hegemonic subjectivity, on the other hand, is speaking in hegemonic terms. Every hegemonic subject, strictly speaking, could at certain historical moments cede into subalternity, sometimes totally, but often partially, and the extent of this oscillation between subjectivity and subalternity depends on his or her subject positions. This happens through hegemonic re-grounding in which several formerly hegemonic narratives slip into ineffability. Moreover, the subaltern can speak only when they are spoken to through a structural locution. However, such speaking does not, indeed cannot, transcend their subalternity. Subalternity is overcome when the subaltern speak back to the structure of subalternity not in terms imposed by the latter's discourse but in terms that undermine, at times subvert, the hegemonic terms of the structure. Subalternity is ended, in other words, when locution becomes interlocution (in Gramsci (1971: 55), "permanent victory"). In the absence of hegemonic re-grounding, which amounts to the presence of epistemic violence, the experience of subalternity becomes potentially subversive, given that it can find effable terms to articulate the experience of subalternity in partially-hegemonic terms, as it does not conform to the structural principles of locution. And the most challenging task in this process is to find a common, but not necessarily compromising, language. This shows that a radical indeterminacy penetrates the relation between hegemonic re-grounding and epistemic violence. Nonetheless, as it is often the case, a common language can be constructed through the hegemonic worldview. That is why colonial dominance must turn itself into hegemony if it is intent upon securing its presence in the lives of the colonized.

What is more, subalternity refers to a particular mode of constitution of the subjectnamely, constitution through exclusion or marginalization. What is important, though, is that subalternity alludes to the conditions in which the hegemonic re-grounding of the life-world has failed. In such cases, the hegemonizing Self, having failed to provide a common language that would bring the Other into interlocution, loses communication with those it wishes to hegemonize and as such automatically pushes the Other back into its subalternity. That is why subalternity of the Other can only be accomplished through an act of epistemic violence. By taking away the familiar, (the colonial) dominance inserts alien worldviews and modes of praxis into the consciousness of the subaltern. As such, it brings the operation of the subaltern's existing (and in many cases age-long) experiential knowledges into a halt (however temporary). This is perhaps most evident in the bloody conquest of the Americas by the collaboration of the Spaniards and the Church (indeed an extreme case), where some indigenous people mistook the horse and the rider as one 
creature or saw firearms as lightingbolts sent down upon the will of the God-like conquerors, and in the midst of confusion and disease, perceived the ruthless pandemonium of greed as divine punishment. It would be a mistake, however, if we reduced epistemic violence to such apocalyptic moments of civilizational conquest. But, aside from extreme cases, epistemic violence and thereby marginalization (of which exclusion is an extreme variation) are built-in features of all hegemonies. Chandra's unfortunate fate stems from the decision that could not transcend her marginality. The hegemonic fiat that Chandra faced (abortion or bhek!) deprived her from knowledges beyond this binary. What is noteworthy about her case is that the colonial legal discourse did not clash with the colonized culture in this incident. The silence of colonial humanism would in fact momentarily escape the colonizer-colonized binary and reinforce the hegemony of the traditional samaj law.

Subalternity is overcome through a creative act, an act of decision, which attests to the attempt at re-grounding one's life-world. The re-grounding could lead to the hegemonization of the subaltern-turned-subject. But it also could potentially lead to the emergence of a new hegemonic subject. The creative act is born out of the point of interlocution between the experience of subalternity and an alternative horizon of possibilities - an interlocution that reveals a divided subject that nonetheless moves toward a possible total-horizon of existence. And that is how, as an attempt at potentiating a new hegemony, and forming a new subject, the subaltern becomes an organic intellectual. 


\section{REFERENCES}

Baxi, U. 1992. “The State's Emissary': The Place of Law in Subaltern Studies.” In Subaltern Studies VII: Writing on Southeast Asian History and Society. Partha Chatterjee \& Gyanendra Pandey (eds.). Delhi: Oxford University Press, pp. 247-64.

Bhabha, H.K. 1994. The Location of Culture. London/New York: Routledge.

Chakrabarty, D. 1985. "Invitation to a Dialogue." In Subaltern Studies VI: Writing on Southeast Asian History and Society. Ranajit Guha (ed.). Delhi: Oxford University Press, pp. 364-76.

Chatterjee, P. 1992. "Caste and Subaltern Consciousness." In Subaltern Studies VI: Writing on Southeast Asian History and Society. Ranajit Guha (ed.). Delhi: Oxford University Press, pp. 169-209.

Das, V. 1992. "Subaltern as Perspective.” In Subaltern Studies VI: Writing on Southeast Asian History and Society. Ranajit Guha (ed.). Delhi: Oxford University Press, pp. 311-24.

Day, J.F.R. 2005. Gramsci Is Dead: Anarchist Currents in the Newest Social Movements. London/Toronto: Pluto Press/Between the Lines.

Golding, S. 1992. Gramsci's Democratic Theory: Contributions to a Post-Liberal Democracy. Toronto: Univeristy of Toronto Press.

Gramsci, A. 1994. Letters from Prison Volume 2. Frank Rosengarten (ed.). New York: Columbia University Press.

Gramsci, A. 1971. Selections from the Prison Notebooks. Quintin Hoare \& Geoffrey Nowell Smith (eds.). New York: International Publishers.

Guha, R. 1996. "The Small Voice of History." In Subaltern Studies IX: Writing on Southeast Asian History and Society. Shahid Amin \& Dipesh Chakrabarty (eds.). Delhi: Oxford University Press, pp. 1-12.

Guha, R. 1992. "Discipline and Mobilize.” In Subaltern Studies VII: Writing on Southeast Asian History and Society. Partha Chatterjee \& Gyanendra Pandey (eds.). Delhi: Oxford University Press, pp. 69-120. 
Guha, R. 1989. "Dominance without Hegemony and its Historiography." In Subaltern Studies VI: Writing on Southeast Asian History and Society. Ranajit Guha (ed.). Delhi: Oxford University Press, pp. 210-309.

Guha, R. 1988. "The Prose of Counter-Insurgency.” In Selected Subaltern Studies. Ranajit Guha \& Gayatri Chakravorty Spivak (eds.). New York: Oxford University Press, pp. 45-84.

Guha, R. 1987. “Chandra's Death.” In Subaltern Studies V: Writings on South Asian History and Society. Ranajit Guha (ed.). Delhi: Oxford University Press, pp. 135-65.

Guha, R. 1982. "On Some Aspects of the Historiography of Colonial India." In Subaltern Studies I: Writings on South Asian History and Society. Ranajit Guha (ed.). New York: Oxford University Press, pp. 1-8.

Ives, P. 2004. Language and Hegemony in Gramsci. London: Pluto Press.

Laclau, E. \& C. Mouffe. 1985. Hegemony and Socialist Strategy: Toward A Radical Democratic Politics. London: Verso.

Landry, D. \& G. MacLean (eds.). 1996. The Spivak Reader. New York/London: Routledge.

Maciavelli, N. 1979. The Prince. Peter Bondanella (ed.). London: Oxford University Press.

Moore-Gilbert, B. 1997. Postcolonial Theory: Contexts, Practices, Politics. London/New York: Verso.

Said, E. 1979. Orientalism. Toronto: Random House Canada.

Sen, A. 1987. "Subaltern Studies: Capital, Class and Community." In Subaltern Studies V: Writings on South Asian History and Society. Ranajit Guha (ed.). Delhi: Oxford University Press, pp. 203-35.

Spivak, G.C. 1990. The Post-Colonial Critic: Interviews, Strategies, Dialogues. Sarah Harasym (ed.). New York/London: Routledge.

Spivak, G.C. 1988a. "Can the Subaltern Speak?" In Marxism and the Interpretation of Culture. Cary Nelson \& Lawrence Grossberg (eds.). Urbana/Chicago: University of Illinois Press, pp. 271-313. 
Spivak, G.C. 1987a. "Explanation and Culture: Marginalia." In In Other Worlds: Essays in Cultural Politics. New York/London: Methuen, pp. 103-17.

Vahabzadeh, P. 2003. Articulated Experiences: Toward A Radical Phenomenology of Contemporary Social Movements. Albany, NY: State University of New York Press. 